\title{
ACE2: The Major Cell Entry Receptor for SARS-CoV-2
}

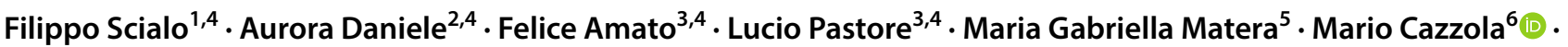 \\ Giuseppe Castaldo ${ }^{3,4} \cdot$ Andrea Bianco $^{1}$
}

Received: 15 September 2020 / Accepted: 5 November 2020 / Published online: 10 November 2020

(c) Springer Science+Business Media, LLC, part of Springer Nature 2020

\begin{abstract}
Despite the unprecedented effort of the scientific community, the novel SARS-CoV-2 virus has infected more than 46 million people worldwide, killing over one million two hundred thousand. Understanding the mechanisms by which some individuals are more susceptible to SARS-CoV-2 infection and why a subgroup of them are prone to experience severe pneumonia, and death should lead to a better approach and more effective treatments for COVID-19. Here, we focus our attention on ACE2, a primary receptor of SARS-CoV-2. We will discuss its biology, tissue expression, and post-translational regulation that determine its potential to be employed by SARS-CoV-2 for cell entry. Particular attention will be given to how the ACE2 soluble form can have a great impact on disease progression and thus be used in a potential therapeutic strategy. Furthermore, we will discuss repercussions that SARS-CoV-2/ACE2 binding has on the renin-angiotensin system and beyond. Indeed, although mostly neglected, ACE2 can also act on [des-Arg 937]-bradykinin of the kinin-kallikrein system regulating coagulation and inflammation. Thorough comprehension of the role that ACE2 plays in different pathways will be the key to assess the impact that SARS-CoV-2/ACE2 binding has on organismal physiology and will help us to find better therapies and diagnostic tools.
\end{abstract}

Keywords SARS-CoV-2 · ACE2 receptor · COVID-19

\section{Introduction}

In the last 20 years, humanity has witnessed an increasing number of pandemics that have hospitalized or killed hundreds of thousands of people, leaving our healthcare systems under unprecedented pressure. Severe acute respiratory syndrome (SARS) in 2002 and Middle East respiratory syndrome in 2012 (MERS) [1], and more recently the novel

Mario Cazzola

mario.cazzola@uniroma2.it

1 Dipartimento di Scienze Mediche Traslazionali, University of Campania “L. Vanvitelli”, Naples, Italy

2 Dipartimento di Scienze e Tecnologie Ambientali Biologiche Farmaceutiche, University of Campania "L. Vanvitelli", Naples, Italy

3 Dipartimento di Medicina Molecolare e Biotecnologie Mediche, Università Di Napoli Federico II, Naples, Italy

4 CEINGE, Biotecnologie Avanzate, Naples, Italy

5 Dipartimento di Medicina Sperimentale, University of Campania “L. Vanvitelli”, Naples, Italy

6 Dipartimento di Medicina Sperimentale, University of Rome "Tor Vergata", Rome, Italy infection named COVID-19, detected in Wuhan China in 2019 are caused by closely related coronaviruses, SARSCoV, MERS-CoV and SARS-CoV-2, respectively [2]. Their unexpected and periodic appearance combined with a high level of human-to-human transmission has made coronaviruses a threat to our societies and economies, forcing us to think not if but when another pandemic will arise. From this perspective, more needs to be done to better understand the mechanism of infection, if and how the hyperactivation of the immune reaction can be prevented, and which treatments can be provided, especially for people with comorbidities.

In this review, a focus will be given to the metallocarboxyl peptidase angiotensin receptor (ACE) 2 that is used by SARS-CoV-2 to gain entry into human cells [3]. There are two forms of ACE2 [4]. The full-length mACE2 is located on cell membranes and consists of a transmembrane anchor and an extracellular domain. It is the receptor site for the spike (S) proteins of SARS-CoV-2. The S proteins on the envelope of SARS-CoV-2 are cleaved into S1 and $\mathrm{S} 2$ subunits, the $\mathrm{S} 1$ protein/receptor interaction being the pivotal determinant for SARS-CoV-2 to infect a host species [3]. The second form, sACE2, is a soluble form that is shed into the circulation [4]. This form of ACE lacks 
membrane anchors and circulates in low concentrations. We will assess whether the level of expression of ACE2 and the ratio between $\mathrm{mACE} 2$ and sACE2 could explain why some people experience more severe symptoms than others. Furthermore, we will discuss the key role that ACE2 plays in regulating molecular pathways that go beyond the renin-angiotensin-aldosterone system (RAAS) and have been mostly ignored. We believe that efforts towards the full comprehension of the intricate roles that ACE2 plays in maintaining organismal physiology will be the key to better understand the multisystemic COVID-19 disease and help us to develop better therapies and diagnostic tools.

\section{Cell Entry Receptors: Lessons from Other Respiratory Viruses}

Cell entry receptors are undoubtedly the key factors determining the tropism and influencing the severity of infection of a specific virus. Furthermore, the high rate of mutations to which these viruses are subject can allow them to change their specificity or binding affinity for a specific receptor. For instance, CoV-NL63, SARS-CoV, and SARS-CoV-2 use ACE2, but CoV-NL63 leads to mild respiratory tract illness, probably because of its low-affinity interaction with the receptor [5]. Although belonging to the same genus of its related SARS-CoV/-2 (Table 1), MERS-CoV binds to dipeptidyl peptidase-4 (DPP4) [6] that plays an important role in glucose metabolism, apoptosis, and the immune system.

Coronaviruses are not the only family of viruses able to cause respiratory tract illness in humans. The A(H1N1) pdm09 influenza virus that caused the pandemic in 2009 shows a different tropism binding to $\alpha 2-6$ - and $\alpha 2-3$-linked sialyl glycans [7] that are present on different cell types and play key roles in cellular communication and cell signaling among others. Finally, human rhinoviruses (HRV), which can cause severe illness if in combination with pre-existing conditions [8], use mainly the membrane form of the intercellular adhesion molecule-1 (ICAM-1) that is expressed in nasal and bronchial epithelial cells [9]. This interaction has been demonstrated to regulate differently the two soluble and membrane-bound forms, suggesting a different role during the infection [10].

Table 1 Human viruses strains

\begin{tabular}{|c|c|c|c|c|c|c|c|}
\hline $\begin{array}{l}\text { Human viruses } \\
\text { strains }\end{array}$ & Genus & $\begin{array}{l}\text { Major cell recep- } \\
\text { tor }\end{array}$ & First report & Animal reservoir & Intermediate host & Pathology & Diagnostic test \\
\hline $\mathrm{HCoV}-\mathrm{OC} 43$ & Betacoronavirus & $\begin{array}{l}\text { Sialic acid, } \\
\text { HLA class I } \\
\text { molecule }\end{array}$ & 1966 & Rodent & Bovine & $\begin{array}{l}\text { Mild respiratory } \\
\text { tract illness }\end{array}$ & $\begin{array}{l}\text { RT-PCR, IF, } \\
\text { ELISA, WB }\end{array}$ \\
\hline $\mathrm{HCoV}-229 \mathrm{E}$ & $\begin{array}{l}\text { Alphacorona- } \\
\text { virus }\end{array}$ & $\begin{array}{l}\text { Human amin- } \\
\text { opeptidase N }\end{array}$ & 1967 & Bat & Dromedary & $\begin{array}{l}\text { Mild respiratory } \\
\text { tract illness }\end{array}$ & $\begin{array}{l}\text { RT-PCR, IF, } \\
\text { ELISA, WB }\end{array}$ \\
\hline HCoV-NL63 & $\begin{array}{l}\text { Alphacorona- } \\
\text { virus }\end{array}$ & ACE2 & 2004 & Bat & Unknown & $\begin{array}{l}\text { Mild respiratory } \\
\text { tract illness }\end{array}$ & $\begin{array}{l}\text { RT-PCR, IF, } \\
\text { ELISA, WB }\end{array}$ \\
\hline HCoV-HKU1 & Betacoronavirus & Sialic acid & 2005 & Rodent & Unknown & $\begin{array}{l}\text { Mild respiratory } \\
\text { tract illness }\end{array}$ & $\begin{array}{l}\text { RT-PCR, IF, } \\
\text { ELISA, WB }\end{array}$ \\
\hline SARS-CoV & Betacoronavirus & ACE2 & 2003 & Bat & Pangolin & $\begin{array}{l}\text { Severe acute } \\
\text { respiratory } \\
\text { syndrome }\end{array}$ & $\begin{array}{l}\text { RT-PCR, IF, } \\
\text { ELISA, WB }\end{array}$ \\
\hline MERS-CoV & Betacoronavirus & DPP4 & 2012 & Bat & Dromedary & $\begin{array}{l}\text { Severe acute } \\
\text { respiratory } \\
\text { syndrome }\end{array}$ & $\begin{array}{l}\text { RT-PCR, IF, } \\
\text { ELISA, WB }\end{array}$ \\
\hline SARS-CoV-2 & Betacoronavirus & ACE2 & 2020 & Bat & Pangolin & $\begin{array}{l}\text { Severe acute } \\
\text { respiratory } \\
\text { syndrome }\end{array}$ & $\begin{array}{l}\text { RT-PCR, IF, } \\
\text { ELISA, WB }\end{array}$ \\
\hline AH1N1 & Orthomyxovirus & Sialic acid & 2009 & None & None & $\begin{array}{l}\text { Respiratory tract } \\
\text { illness }\end{array}$ & $\begin{array}{l}\text { RT-PCR, IF, } \\
\text { ELISA, WB }\end{array}$ \\
\hline Rhinoviruses & Picornaviridae & ICAM-1 & 1956 & None & None & $\begin{array}{l}\text { Mild respiratory } \\
\text { tract illness } \\
\text { Asthma/COPD } \\
\text { exacerbations }\end{array}$ & $\begin{array}{l}\text { RT-PCR, IF, } \\
\text { ELISA, WB }\end{array}$ \\
\hline
\end{tabular}

List of human viruses strains. Human Coronavirus-OC43 (HCoV-OC43), Human Coronavirus-229E (HCoV-229E), Human Coronavirus-NL63 (HCoV-NL63), Human Coronavirus-HKU1 (HCoV-HKU1), Severe acute respiratory syndrome-Coronavirus (SARS-CoV), Severe acute respiratory syndrome-Coronavirus-2 (SARS-CoV-2), Middle east respiratory syndrome-Coronavirus, Influenza A virus subtype H1N1 (A/H1N1), Angiotensin converting enzyme 2 (ACE2), Dipeptidyl peptidase-4 (DPP4), Intercellular adhesion molecule-1 (ICAM1), Reverse transcriptasepolymerase chain reaction (RT-PCR), Immuno-fluorescence (IF), Enzyme-linked immunosorbent assay (ELISA), Western Blot (WB) 


\section{Biology, Tissue Expression, and Post-translational Modifications of ACE2 Receptor}

\section{Biology}

ACE2 was initially identified in 2000 as a homolog of the ACE receptor, sharing $40 \%$ identity and $60 \%$ similarity, respectively $[11,12]$. Located on the $\mathrm{X}$ chromosome and precisely mapping on chromosomal location $\mathrm{Xp} 22$, it is formed by 18 exons and 20 introns generating 6 variants through alternative splicing [13]. ACE2, which consists of 805 amino acids, has only a single extracellular N-terminal domain containing the active catalytic site domain, a C-terminal membrane anchor, and a conserved HEXXH zinc-binding domain [11]. It acts as a carboxypeptidase removing single amino acids from the C-terminus of its substrates [14].

Experimental evidence has demonstrated that in the situation of cell energy stress, sirtuin 1 (SIRT1) can mediate ACE2 transcriptional activation [15]. Similarly, the reduced ACE2 level in apelin deficient mice was corrected by apelin treatment [16] suggesting that apelin acts as a positive regulator of ACE2 expression and might have a role in affecting other pathways regulated by ACE2. Apelins are a family of peptides that activate the apelin receptor, which physically interacts with the angiotensin type I receptor (AT1R) [17], forcing it into a low-affinity state and reducing the binding and signaling of angiotensin II (AngII) [18]. Conversely, the microRNA 421 (miR421) has been shown to target a binding site in the 3'-UTR of ACE2 transcript, negatively regulating the receptor [19].

\section{ACE2 Tissue Expression}

Due to the wide spectrum of symptoms occurring in people affected by COVID-19, efforts have been made to study ACE2 tissue expression in both mRNA and protein levels, identifying the organs more susceptible to this infection. Surprisingly, the analysis of ACE2 expression in experimental models and in human transcriptome by using different databases revealed that it is very low in the lung, mainly limited to a small fraction of type II alveolar epithelial cells [20-22]. Since most people present respiratory difficulties in response to SARS-CoV-2 infection, these findings were explained by the fact that the release of inflammatory cytokines, such as interferons (IFNs) caused by SARS-CoV-2, can increase the expression ACE2 and potentiate the infection [23, 24]. However, Onabajo and colleagues recently showed that IFNs stimulation upon viral treatment induced the expression of a truncated ACE2 isoform designate as $\delta$ ACE2, which lacks $356 \mathrm{~N}$-terminal amino acids, is not able to bind SARSCoV-2 and, therefore, does not contribute to the potentiation of the infection [25].

Furthermore, the analysis of ACE2 mRNA and protein expression in experimental models, and evaluation of three different databases have demonstrated that small intestine, testis, kidney, heart muscle, colon, and thyroid gland are the overlapping tissues with the highest level of ACE2 expression, with no expression detected in blood cells [20, 26]. These data explain why people affected by COVID-19 experience gastrointestinal problems and kidney dysfunction [27, $28]$.

\section{ACE2 Expression in Pathological Conditions}

Several clinical reports have suggested that male sex combined with increasing age [29], smoking, and pre-existing comorbidities [30] represent risk factors for a poor outcome from the infection. Whether there is upregulation of ACE2 expression in smokers that could increase their sensitivity to infection is still a matter of debate. In the literature, there are reports supporting [31-33] and refuting [34-36] this hypothesis.

Since the beginning of the COVID-19 pandemic, hypertension and diabetes have been correlated with higher risk of mortality, and initial reports speculated that angiotensin converting enzyme inhibitors (ACEi) and angiotensin receptor blockers (ARBs), which are commonly used therapeutic agents for these conditions, would up-regulate ACE2 expression, thus increasing the risk of severe illness [37]. Recent evidence has challenged this hypothesis, demonstrating both mechanistically and in large cohort studies that ACEi and ARBs do not up-regulate ACE2 and are not associated with an increased mortality $[35,36]$.

Interestingly, asthma has not been reported as a risk factor for COVID-19 illness and disease progression. Kimura and colleagues showed that interleukin (IL)-13, a cytokine up-regulated in type 2 asthma, down-regulates the level of ACE2 [38]. Furthermore, Jackson and colleagues demonstrated a negative correlation between ACE2 expression and allergen sensitization and asthma [39]. Intriguingly, Peters and colleagues found that asthmatic subjects treated with inhaled corticosteroids (ICS) had low ACE2 expression compared with untreated subjects, a finding suggesting that ICS treatment could be a predictor of decreased susceptibility to SARS-CoV-2 infection [40].

\section{ACE2 Post-translational Modification}

ACE2 is normally localized on the plasma membrane (mACE2) with the N-terminal containing the catalytic site protruding on the extracellular space using as substrate 
different active peptides present in the interstitium. ACE2 can undergo proteolytic shedding by different proteases such as a disintegrin and metalloproteinase domain-containing protein (ADAM)10, ADAM17, and transmembrane protease, serine 2 (TMPRSS2). Binding of S1 subunit of the Spike protein of SARS-CoV-2 to the ACE2 receptor triggers the cleavage of ACE2 by ADAM17/tumor necrosis factorconverting enzyme (TACE) at the ectodomain sites [41] and a soluble form that retains its catalytic activity (sACE2) is produced [42]. Interestingly, TACE inhibitors can decrease viral entry in vitro and in vivo demonstrating their key role in determining SARS-CoV infectivity and their potential use as a target for antiviral therapies [43].

The significance of ACE2 shedding has not been fully elucidated, but in the context of the COVID-19 pandemic, the comprehension of the mechanism leading to ACE2 shedding, sACE2 function, and its plasma level can lead to the development of better therapies and diagnostic tools to follow disease progression and severity. For example, it has been shown that the binding of SARS-CoV with ACE2 induced ADAM17-dependent shedding, promoting SARS$\mathrm{CoV}$ uptake into the cells [44].

TMPRSS2 is able to promote ACE2 proteolytic cleavage using different targets in the protein sequence. It cleaves ACE2 at the intracellular C-terminal domain and, differently from ADAM17 [45], does not produce a soluble form that retains the catalytic function [41]. However, like ADAM17, it is essential for SARS-CoV entry into the cell $[45,46]$.

ACE2 shedding can be stimulated by proinflammatory cytokines such as IL-1 $\beta$ and tumor necrosis factor (TNF)- $\alpha$, and endotoxin [47] that could result in a positive effect reducing SARS-CoV-2 entry, but at the same time, may cause an increase in AngII and further activation of the AngII/AT1R axis worsening inflammation (discussed below) (Fig. 1). Different studies have demonstrated that an

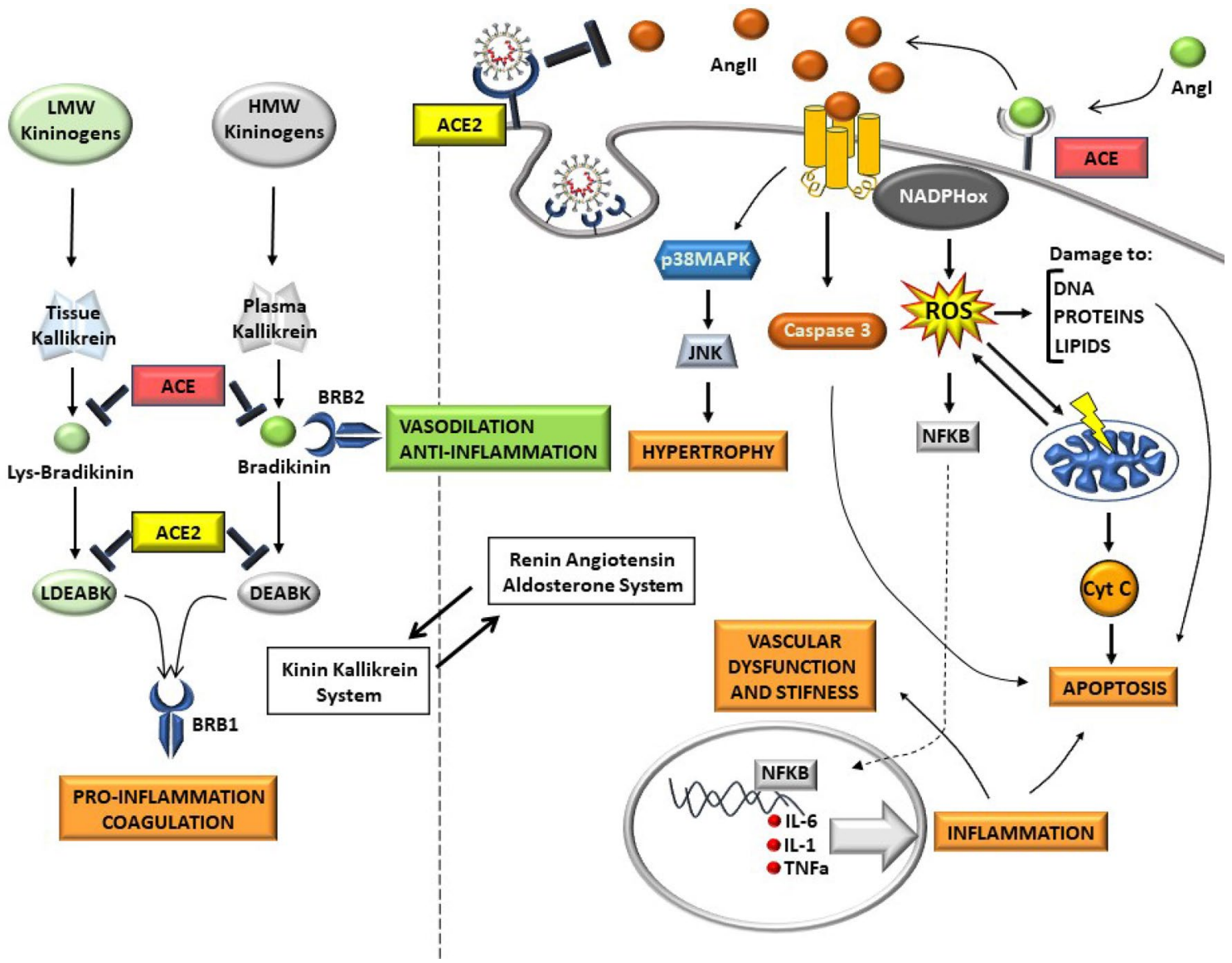

Fig. 1 SARS-CoV-2 infection and dysregulation of the RAAS and KKS. Sars-CoV-2 binding to the ACE2 receptor can cause its internalization and possible dysregulation of both the RAAS and KKS. Indeed, without the counterbalance action of ACE2, AngII is not converted in Ang1-7 and able to overactivate its receptor AT1R promoting vasoconstriction, production of proinflammatory cytokines such as TNF $\alpha$, IL6, IL1, and ROS generation through NADPH oxidase. ACE2 also plays a key role in the regulation of the KKS by inactivating LDEABK and DEABK making them incapable to bind the receptor BRB1. The overactivation of BRB1 receptor has been shown to promote inflammation and coagulation 
increased level of sACE2 correlates with disease severity $[48,49]$, possibly due to an increase in AngII.

Furthermore, an increase in $\mathrm{Ca}^{2+}$ caused by ionomycin treatment induces ADAM10-dependent ACE2 shedding [47], while calmodulin, a calcium modulated protein, by binding to ACE2, inhibits its shedding [50]. These findings highlight the interconnection between $\mathrm{Ca}^{2+}$ signal transduction pathways and ACE2 regulated pathways. The evidence that ACE2 can be cleaved from multiple proteases upon different stimuli indicates that the post-translational regulation of this ectoenzyme is of great importance in managing tissue homeostasis. This explains why its dysregulation caused by SARS-CoV-2 binding has such an intense effect on organismal physiology.

\section{ACE2 Polymorphisms and Susceptibility to SARS-CoV-2 Infection}

Due to the main role of ACE2 in mediating SARS-CoV-2 entry into cells, many studies have speculated whether ACE2 expression and polymorphism and serum sACE2 levels could explain why some people are more prone to experience a severe phenotype while others remain asymptomatic. Previous studies have demonstrated that specific residues in the ACE2 protein are essential for binding with SARS$\mathrm{CoV}$ [51]. Therefore, genomic variability in those specific residues could modulate the binding between ACE2 and the SARS-CoV-2 Spike protein, accounting for a broad range of symptoms exhibited by people affected by COVID-19.

Studies that aimed to find mutations in the ACE2 sequences and allele frequency in different populations have demonstrated the existence of specific variance that could affect SARS-CoV-2 binding [52-54]. Furthermore, a bioinformatic approach has identified new ACE2 exons that could participate in alternative splicing by producing a truncated ACE2, lacking the $\mathrm{N}$-terminus that could not bind the Spike protein, or the C-terminus generating a soluble ACE2 that would again reduce virus/cell binding and infectivity [55]. Identification of a genomic variability in TMPRSS2 that affects its expression is worthy of mention because it suggests that European and American populations could be more susceptible to SARS-CoV-2 infection [56].

We do not yet know whether a specific variability in the ADAM17 sequence is associated with a high level of sACE2 and whether there is a correlation with the SARS-CoV-2 infection. Indeed, since the beginning of this pandemic, opposite assumptions have been made. Some researchers think that elevated levels of sACE2 may be protective because they are capable of inhibiting the binding of SARSCoV-2 to membrane-bound ACE2 [4] and would explain why women and children are less susceptible [57]. Conversely, recent studies have shown that high levels of sACE2 could be evidence of increased ACE2 expression, elevated ADAM1 7 activity or both and, therefore, greater susceptibility to SARS-CoV-2 infection [58, 59].

\section{Physiological Functions of ACE2}

Dissecting the roles that ACE2 has in maintaining organismal physiology will help us to better comprehend why its dysregulation caused by SARS-CoV-2 can have such a devastating effect, especially in the elderly with comorbidities. In the next sections, we will describe the molecular pathways in which ACE2 plays an important role. We will focus on the role that ACE2 plays in counterbalancing the RAAS but also on its important function in the kinin-kallikrein system (KKS) that has been mostly neglected although it plays an essential part in regulating the inflammatory process.

\section{ACE2 and the RAAS}

Despite having a high degree of homology with ACE, ACE2 shows a remarkable difference in substrate selection, catalyzing with high efficiency the conversion of the vasoconstrictor AngII in Ang1-7 that binds and activates its own seven-transmembrane G protein-coupled receptor (GPCR) called MAS to exert anti-inflammatory and anti-remodeling effects or, with less efficiency, the formation of Ang1-9 from AngI, which can be converted to Ang1-7 by ACE [60]. In doing so, ACE2 plays a counterbalance action in the RAAS, which is a critical regulator of blood volume and systemic vascular resistance and contributes to sodium reabsorption, inflammation, and fibrosis, preventing the possible adverse effect of AngII accumulation.

The interaction between SARS-CoV2 and ACE2 could negatively regulate the receptor [61] causing, in turn, an accumulation of AngII that through the unopposed RAAS activation via the AngII/AT1R can cause vasoconstriction, oxidative stress, inflammation, atrophy, and fibrosis [62]. There is evidence that AT1R can induce apoptosis in lung alveolar epithelial cells in response to AngII in rat and human alveolar epithelial cells [63]. Furthermore, AngII promotes endothelial dysfunction through cyclooxygenase-2 (COX-2) activation, which generates vasoactive prostaglandins and reactive oxygen species (ROS) [64]. Excessive production of ROS upon overactivation of the AngII/AT1R/ nicotinamide adenine dinucleotide phosphate (NADPH) oxidase axis has been correlated with hypertension [65], and atherosclerosis [66], and can induce apoptosis through the release of cytochrome $\mathrm{C}$ from damaged mitochondria, activation of caspase 3 or p38 mitogen-activated protein kinase (MAPK)/Jun N-terminal kinase (JNK) cascade. Other inflammatory mechanisms activated by an accumulation of 
AngII can also involve the activation of nuclear factor (NF)$\mathrm{kB}$ and transcription of the proinflammatory cytokines IL-6, IL-1 $\beta$, and TNF $\alpha 30$ [67] (Fig. 1). Therefore, the activation of the immune response caused by the infection in combination with the high level of AngII could result in the hyperinflammatory state that is seen in the late phase of SARS-CoV-2-infected patients.

\section{Angiotensin A/ACE2/Alamandine/ MAS-Related GPCR D (MrgD) Axis}

Ang A differs from AngII by a single amino acid (alanine) at the N-terminal. It shows affinity to AT1R and possibly activates all aforementioned pathways in the context of SARS-CoV-2 infection. As in the case of AngII, ACE2 is responsible for providing a further layer in RAAS regulation by catalyzing the conversion of AngA in alamandine. This conversion highlights again the key role of ACE2 in the regulation of RAAS. In fact, the produced peptide alamandine is able to bind to the MAS-related GPCR member D (MrgD) and exerts a protective action promoting vasorelaxation and an antiproliferative effect [68].

\section{ACE2 and the Kinin-Kallikrein System (KKS)}

The KKS plays a key role in the regulation of several physiological processes such as coagulation, inflammation, and pain [69]. It exerts its action through the production of active peptides such as bradykinin (BK), Lys-BK, [des-Arg9]-BK (DEABK), and Lys-[des-Arg9]-BK (LDEABK) [70]. By binding to bradykinin receptor-B2 (BRB2), BK and LysBK induce a local increase in nitric oxide production that has a potent vasodilator effect counterbalancing the vasopressor effect of the RAAS [71]. Moreover, BK positively regulates tissue plasminogen secretion (tPA) and, therefore, plays an important role in thrombus formation [72]. DEABK and LDEABK act on bradykinin receptor-B1 (BRB1) and have important role in the inflammation process [73, 74]. In fact, differently from BRB2, BRB1 is expressed at very low level on endothelial cells but is induced upon tissue injury and is up-regulated by proinflammatory cytokine release such as IL-1B, TNF $\alpha$, IL-2, and IFN $\gamma$ [73]. Evidence has demonstrated that activation of BRB1 is able to aggravate the inflammation by causing the further release of proinflammatory cytokines and promoting neutrophil infiltration [75]. Therefore, DEABK and LDEABK can act as proinflammatory factors that exert their function through the $\mathrm{BRB} 1$ receptor.

It is interesting to note that ACE2, which does not inactivate $\mathrm{BK}$, can cleave the terminal residue in DEABK and LDEABK, rendering them unable to interact with BRB1 [76,
77]. Therefore, ACE2 internalization due to SARS-CoV-2 infection will create an imbalance in the KKS system causing an overactivation of the DEABK/LDEABK/BRB1 axis, contributing to increased inflammation and rendering the lung environment more prone to local vascular leakage, leading to angioedema [76]. Consequently, approaches aimed at targeting the RAAS system, but not the KKS, will not be as effective in limiting the state of hyperinflammation typical of severe cases of SARS-CoV-2 infection (Fig. 1). The role of a dysregulated KKS remains theoretical in COVID-19 [78]. Nonetheless, an approach that could target both pathways to fight against COVID-19 has already been suggested [79].

\section{ACE2 as a Target for a SARS-CoV-2 Therapeutic Strategy}

ACE2 is attracting much interest as a therapeutic target in the fight against COVID-19 [4]. As described earlier, ACE2 can be shed from the cell and released into the circulation by ADAM17 while maintaining its catalytic activity and ability to bind SARS-CoV-2. It has been suggested to use human recombinant ACE-2 (hrACE2) protein to saturate the viral S-protein and thus prevent cellular entry of SARS-Cov-2 [4]. Soluble hrACE2 (shrACE2) retains attractive physiological features due to its ability to inactivate SARS-CoV-2 present in the extracellular milieu. Differently from antiviral or anti-inflammatory therapies, shrACE2 can act upstream by decreasing the binding between SARS-CoV-2/mACE2, thus reducing infectivity [80]. Furthermore, it can also counteract the increase in AngII and DEABK/LDEABK preserving lung function. Administration of hrACE2 is well tolerated in healthy subjects [81], and it has been successfully used to treat patients with ARDS [82]. APN01 is a rhACE2 that is fully glycosylated (7 glycosylation sites) and occurs as a stable noncovalent homodimer. Its enzymatic activity relies on incorporated $\mathrm{Zn}^{2+}$. The use of twice-daily doses of APN01 infusion resulted in a rapid decrease in plasma AngII levels and an increase in Ang1-7 and Ang1-5 levels, as well as a trend to a decrease in plasma IL-6 concentrations [82]. Recently, Monteil and colleagues demonstrated that shrACE2 can decrease SARS-CoV-2 infection in vitro [83], and clinical trials are already underway (Clinicaltrials. gov \#NCT04335136). Furthermore, a more effective way for the delivery of shrACE2 that would decrease protease degradation has already been suggested [84]. Although our knowledge of the role that endogenous SACE2 plays in human physiology is still limited, there is promising evidence that shrACE2 could be used as a valid therapy for SARS-CoV-2 infection.

Other potential therapeutic approaches include a SARSCoV-2 spike protein-based vaccine, a TMPRSS inhibitor to block the priming of the spike protein, and blockage of 
the surface ACE2 receptor by using anti-ACE2 antibody or peptides [81]. Camostat mesylate, approved in Japan to treat pancreatic inflammation, has been shown to block TMPRSS 2 activity and prevent cellular infection by SARSCov-2 [45]. Another strategy that is being investigated in clinical trials is the administration of an antibody or a singlechain antibody fragment ( $\mathrm{scFv}$ ) that binds ACE2 and blocks the interaction of spike protein on the virion to ACE2 [85].

Furthermore, beyond the RAAS and KKS, ACE2 has been shown to act on other substrates such as apelin-13/17, neurotensin (1-11), $\beta$-casomorphin-(1-7), dynorphin A (1-13), and ghrelin among others [86]. These substrates are interesting potential therapeutic targets for COVID-19 [77], but we will not discuss them because their involvement in COVID-19 is still highly speculative.

\section{Conclusion}

Since the first outbreak in Wuhan, China, SARS-CoV-2 has spread worldwide, killing over one million two hundred thousand people. The rapid rate of adaptive mutations combined with high transmissibility renders coronaviruses an ongoing threat of causing future pandemics, with especially high risk for the elderly [87]. Although the scientific world is making an extraordinary effort, we are still far from fully understanding whether the overactivation of the immune system and the state of hyperinflammation due to SARSCoV-2 infection can be controlled [88].

This would be particularly important in people with comorbidities such as diabetes and hypertension, which are conditions already associated with an inflammatory state. It is likely, even if not yet fully ascertained, that when these pathological states combine with the viral infection, the dysregulation of both the RAAS and the KKS due to ACE2 internalization mediated by SARS-CoV- 2 could create the conditions for severe illness and a fatal outcome.

In conclusion, we believe that further efforts should be made to fully understand ACE2 transcriptional regulation and post-translational modification during the course of COVID-19 and in response to treatments. In fact, as already discussed, contrasting hypotheses have been formulated concerning the effect of therapies taken by millions of people that might increase ACE2 expression and susceptibility to SARS-CoV-2 infection. Furthermore, although COVID-19 is still primarily described as a respiratory viral illness, it is increasingly evident that it is a multisystemic disease. Therefore, it is essential to acquire a greater knowledge of the role that ACE2 plays in different organs and physiological pathways because of its widespread tissue expression. This may shed light on factors that modulate cell surface ACE2 receptor affecting viral cell entry and consequently susceptibility to SARS-CoV-2 infection. This, in turn, could have significant implications for identifying better therapies and screening tools to assess disease progression and severity.

\section{Compliance with Ethical Standards}

Conflict of interest The authors declare that they have no known competing financial interests or personal relationships that could have appeared to influence the work reported in this paper.

\section{References}

1. Cui J, Li F, Shi ZL (2019) Origin and evolution of pathogenic coronaviruses. Nat Rev Microbiol 17(3):181-192. https://doi. org/10.1038/s41579-018-0118-9

2. Zhu N, Zhang D, Wang W, Li X, Yang B, Song J, Zhao X, Huang B, Shi W, Lu R, Niu P, Zhan F, Ma X, Wang D, Xu W, Wu G, Gao GF, Tan W, China Novel Coronavirus Investigating and Research Team (2020) A novel coronavirus from patients with pneumonia in China, 2019. N Engl J Med 382(8):727-733. https://doi. org/10.1056/NEJMoa2001017

3. Samavati L, Uhal BD (2020) ACE2, much more than just a receptor for SARS-COV-2. Front Cell Infect Microbiol 10:317. https:// doi.org/10.3389/fcimb.2020.00317

4. Batlle D, Wysocki J, Satchell K (2020) Soluble angiotensin-converting enzyme 2: a potential approach for coronavirus infection therapy? Clin Sci (Lond) 134(5):543-545. https://doi.org/10.1042/ CS20200163

5. Mathewson AC, Bishop A, Yao Y, Kemp F, Ren J, Chen H, Xu X, Berkhout B, van der Hoek L, Jones IM (2008) Interaction of severe acute respiratory syndrome-coronavirus and NL63 coronavirus spike proteins with angiotensin converting enzyme-2. J Gen Virol 89(Pt 11):2741-2745. https://doi.org/10.1099/ vir.0.2008/003962-0

6. Letko M, Marzi A, Munster V (2020) Functional assessment of cell entry and receptor usage for SARS-CoV-2 and other lineage B betacoronaviruses. Nat Microbiol 5(4):562-569. https://doi. org/10.1038/s41564-020-0688-y

7. Childs RA, Palma AS, Wharton S, Matrosovich T, Liu Y, Chai W, Campanero-Rhodes MA, Zhang Y, Eickmann M, Kiso M, Hay A, Matrosovich M, Feizi T (2009) Receptor-binding specificity of pandemic influenza A (H1N1) 2009 virus determined by carbohydrate microarray. Nat Biotechnol 27(9):797-799. https://doi. org/10.1038/nbt0909-797

8. Bianco A, Whiteman SC, Sethi SK, Allen JT, Knight RA, Spiteri MA (2000) Expression of intercellular adhesion molecule-1 (ICAM-1) in nasal epithelial cells of atopic subjects: a mechanism for increased rhinovirus infection? Clin Exp Immunol 121(2):339-345. https://doi.org/10.1046/j.1365-2249.2000.01301 .X

9. Sethi SK, Bianco A, Allen JT, Knight RA, Spiteri MA (1997) Interferon-gamma (IFN-gamma) down-regulates the rhinovirus-induced expression of intercellular adhesion molecule-1 (ICAM-1) on human airway epithelial cells. Clin Exp Immunol 110(3):362-369. https://doi.org/10.1046/j.1365-2249.1997.42214 40. $\mathrm{x}$

10. Whiteman SC, Bianco A, Knight RA, Spiteri MA (2003) Human rhinovirus selectively modulates membranous and soluble forms of its intercellular adhesion molecule-1 (ICAM-1) receptor to promote epithelial cell infectivity. J Biol Chem 278(14):1195411961. https://doi.org/10.1074/jbc.M205329200 
11. Donoghue M, Hsieh F, Baronas E, Godbout K, Gosselin M, Stagliano N, Donovan M, Woolf B, Robison K, Jeyaseelan R, Breitbart RE, Acton S (2000) A novel angiotensin-converting enzymerelated carboxypeptidase (ACE2) converts angiotensin I to angiotensin 1-9. Circ Res 87(5):E1-9. https://doi.org/10.1161/01. res.87.5.e1

12. Tipnis SR, Hooper NM, Hyde R, Karran E, Christie G, Turner AJ (2000) A human homolog of angiotensin-converting enzyme. Cloning and functional expression as a captopril-insensitive carboxypeptidase. J Biol Chem 275(43):33238-33243. https://doi. org/10.1074/jbc.M002615200

13. Devaux CA, Rolain JM, Raoult D (2020) ACE2 receptor polymorphism: susceptibility to SARS-CoV-2, hypertension, multi-organ failure, and COVID-19 disease outcome. J Microbiol Immunol Infect 53(3):425-435. https://doi.org/10.1016/j.jmii.2020.04.015

14. Turner AJ, Hooper NM (2002) The angiotensin-converting enzyme gene family: genomics and pharmacology. Trends Pharmacol Sci 23(4):177-183. https://doi.org/10.1016/s0165 $-6147(00) 01994-5$

15. Clarke NE, Belyaev ND, Lambert DW, Turner AJ (2014) Epigenetic regulation of angiotensin-converting enzyme 2 (ACE2) by SIRT1 under conditions of cell energy stress. Clin Sci (Lond) 126(7):507-516. https://doi.org/10.1042/CS20130291

16. Sato T, Suzuki T, Watanabe H, Kadowaki A, Fukamizu A, Liu PP, Kimura A, Ito H, Penninger JM, Imai Y, Kuba K (2013) Apelin is a positive regulator of ACE2 in failing hearts. J Clin Invest 123(12):5203-5211. https://doi.org/10.1172/JCI69608

17. Chun HJ, Ali ZA, Kojima Y, Kundu RK, Sheikh AY, Agrawal R, Zheng L, Leeper NJ, Pearl NE, Patterson AJ, Anderson JP, Tsao PS, Lenardo MJ, Ashley EA, Quertermous T (2008) Apelin signaling antagonizes Ang II effects in mouse models of atherosclerosis. J Clin Invest 118(10):3343-3354. https://doi.org/10.1172/ JCI34871.PMID:18769630

18. Siddiquee K, Hampton J, McAnally D, May L, Smith L (2013) The apelin receptor inhibits the angiotensin II type 1 receptor via allosteric trans-inhibition. Br J Pharmacol 168(5):1104-1117. https://doi.org/10.1111/j.1476-5381.2012.02192.x

19. Lambert DW, Lambert LA, Clarke NE, Hooper NM, Porter KE, Turner AJ (2014) Angiotensin-converting enzyme 2 is subject to post-transcriptional regulation by miR-421. Clin Sci (Lond) 127(4):243-249. https://doi.org/10.1042/CS20130420

20. Wang Y, Wang Y, Luo W, Huang L, Xiao J, Li F, Qin S, Song X, Wu Y, Zeng Q, Jin F, Wang Y (2020) A comprehensive investigation of the mRNA and protein level of ACE2, the putative receptor of SARS-CoV-2, in human tissues and blood cells. Int J Med Sci 17(11):1522-1531. https://doi.org/10.7150/ijms.46695

21. Zou X, Chen K, Zou J, Han P, Hao J, Han Z (2020) Singlecell RNA-seq data analysis on the receptor ACE2 expression reveals the potential risk of different human organs vulnerable to 2019-nCoV infection. Front Med 14(2):185-192. https://doi. org/10.1007/s11684-020-0754-0

22. Serfozo P, Wysocki J, Gulua G, Schulze A, Ye M, Liu P, Jin J, Bader M, Myöhänen T, García-Horsman JA, Batlle D (2020) Ang II (angiotensin II) conversion to angiotensin-(1-7) in the circulation is POP (Prolyloligopeptidase)-dependent and ACE2 (angiotensin-converting enzyme 2)-independent. Hypertension 75(1):173-182. https://doi.org/10.1161/HYPERTENSIONAHA .119 .14071

23. Zhuang MW, Cheng Y, Zhang J, Jiang XM, Wang L, Deng J, Wang PH (2020) Increasing host cellular receptor-angiotensinconverting enzyme 2 expression by coronavirus may facilitate 2019-nCoV (or SARS-CoV-2) infection. J Med Virol. https://doi. org/10.1002/jmv.26139

24. Ziegler CGK, Allon SJ, Nyquist SK, Mbano IM, Miao VN, Tzouanas CN, Cao Y, Yousif AS, Bals J, Hauser BM, Feldman J, Muus C, Wadsworth MH II, Kazer SW, Hughes TK,
Doran B, Gatter GJ, Vukovic M, Taliaferro F, Mead BE, Guo Z, Wang JP, Gras D, Plaisant M, Ansari M, Angelidis I, Adler H, Sucre JMS, Taylor CJ, Lin B, Waghray A, Mitsialis V, Dwyer DF, Buchheit KM, Boyce JA, Barrett NA, Laidlaw TM, Carroll SL, Colonna L, Tkachev V, Peterson CW, Yu A, Zheng HB, Gideon HP, Winchell CG, Lin PL, Bingle CD, Snapper SB, Kropski JA, Theis FJ, Schiller HB, Zaragosi LE, Barbry P, Leslie A, Kiem HP, Flynn JL, Fortune SM, Berger B, Finberg RW, Kean LS, Garber M, Schmidt AG, Lingwood D, Shalek AK, Ordovas-Montanes J, HCA Lung Biological Network (2020) SARS-CoV-2 receptor ACE2 is an interferon-stimulated gene in human airway epithelial cells and is detected in specific cell subsets across tissues. Cell 181(5):1016-1035. https://doi. org/10.1016/j.cell.2020.04.035

25. Onabajo OO, Banday AR, Stanifer ML, Yan W, Obajemu A, Santer DM, Florez-Vargas O, Piontkivska H, Vargas JM, Ring TJ, Kee C, Doldan P, Tyrrell DL, Mendoza JL, Boulant S, ProkuninaOlsson L (2020) Interferons and viruses induce a novel truncated ACE2 isoform and not the full-length SARS-CoV-2 receptor. Nat Genet. https://doi.org/10.1038/s41588-020-00731-9

26. Ye M, Wysocki J, Naaz P, Salabat MR, LaPointe MS, Batlle D (2004) Increased ACE 2 and decreased ACE protein in renal tubules from diabetic mice: a renoprotective combination? Hypertension 43(5):1120-1125. https://doi.org/10.1161/01.HYP.00001 26192.27644.76

27. Cholankeril G, Podboy A, Aivaliotis VI, Tarlow B, Pham EA, Spencer SP, Kim D, Hsing A, Ahmed A (2020) High prevalence of concurrent gastrointestinal manifestations in patients with severe acute respiratory syndrome Coronavirus 2: early experience from California. Gastroenterology 159(2):775-777. https:// doi.org/10.1053/j.gastro.2020.04.008

28. Werion A, Belkhir L, Perrot M, Schmit G, Aydin S, Chen Z, Penaloza A, De Greef J, Yildiz H, Pothen L, Yombi JC, Dewulf J, Scohy A, Gérard L, Wittebole X, Laterre PF, Miller SE, Devuyst O, Jadoul M, Morelle J, Cliniques universitaires Saint-Luc (CUSL) COVID-19 Research Group (2020) SARS-CoV-2 causes a specific dysfunction of the kidney proximal tubule. Kidney Int 98(5):1296-1307

29. Boccia M, Aronne L, Celia B, Mazzeo G, Ceparano M, D’Agnano V, Parrella R, Valente T, Bianco A, Perrotta F (2020) COVID19 and coagulative axis: review of emerging aspects in a novel disease. Monaldi Arch Chest Dis. https://doi.org/10.4081/monal di. 2020.1300

30. Vickers C, Hales P, Kaushik V, Dick L, Gavin J, Tang J, Godbout K, Parsons T, Baronas E, Hsieh F, Acton S, Patane M, Nichols A, Tummino P (2002) Hydrolysis of biological peptides by human angiotensin-converting enzyme-related carboxypeptidase. J Biol Chem 277(17):14838-14843. https://doi.org/10.1074/jbc.M2005 81200

31. Jacobs M, Van Eeckhoutte HP, Wijnant SRA, Janssens W, Joos GF, Brusselle GG, Bracke KR (2020) Increased expression of ACE2, the SARS-CoV-2 entry receptor, in alveolar and bronchial epithelium of smokers and COPD subjects. Eur Respir J 56(2):2002378. https://doi.org/10.1183/13993003.02378-2020

32. Leung JM, Yang CX, Tam A, Shaipanich T, Hackett TL, Singhera GK, Dorscheid DR, Sin DD (2020) ACE-2 expression in the small airway epithelia of smokers and COPD patients: implications for COVID-19. Eur Respir J 55(5):2000688. https://doi. org/10.1183/13993003.00688-2020

33. Smith JC, Sausville EL, Girish V, Yuan ML, Vasudevan A, John KM, Sheltzer JM (2020) Cigarette smoke exposure and inflammatory signaling increase the expression of the SARS-CoV-2 receptor ACE2 in the respiratory tract. Dev Cell 53(5):514-529.e3. https ://doi.org/10.1016/j.devcel.2020.05.012

34. Rossato M, Russo L, Mazzocut S, Di Vincenzo A, Fioretto P, Vettor R (2020) Current smoking is not associated with COVID-19. 
Eur Respir J 55(6):2001290. https://doi.org/10.1183/13993 003.01290-2020

35. Lee IT, Nakayama T, Wu CT, Goltsev Y, Jiang S, Gall PA, Liao CK, Shih LC, Schürch CM, McIlwain DR, Chu P, Borchard NA, Zarabanda D, Dholakia SS, Yang A, Kim D, Chen H, Kanie T, Lin CD, Tsai MH, Phillips KM, Kim R, Overdevest JB, Tyler MA, Yan CH, Lin CF, Lin YT, Bau DT, Tsay GJ, Patel ZM, Tsou YA, Tzankov A, Matter MS, Tai CJ, Yeh TH, Hwang PH, Nolan GP, Nayak JV, Jackson PK (2020) ACE2 localizes to the respiratory cilia and is not increased by ACE inhibitors or ARBs. Nat Commun 11(1):5453. https://doi.org/10.1038/s41467-020-19145-6

36. Williamson EJ, Walker AJ, Bhaskaran K, Bacon S, Bates C, Morton CE, Curtis HJ, Mehrkar A, Evans D, Inglesby P, Cockburn J, McDonald HI, MacKenna B, Tomlinson L, Douglas IJ, Rentsch CT, Mathur R, Wong AYS, Grieve R, Harrison D, Forbes H, Schultze A, Croker R, Parry J, Hester F, Harper S, Perera R, Evans SJW, Smeeth L, Goldacre B (2020) Factors associated with COVID-19-related death using OpenSAFELY. Nature 584(7821):430-436. https://doi.org/10.1038/s41586-020-2521-4

37. Furuhashi M, Moniwa N, Mita T, Fuseya T, Ishimura S, Ohno K, Shibata S, Tanaka M, Watanabe Y, Akasaka H, Ohnishi H, Yoshida H, Takizawa H, Saitoh S, Ura N, Shimamoto K, Miura T (2015) Urinary angiotensin-converting enzyme 2 in hypertensive patients may be increased by olmesartan, an angiotensin II receptor blocker. Am J Hypertens 28(1):15-21. https://doi.org/10.1093/ ajh/hpu086

38. Kimura H, Francisco D, Conway M, Martinez FD, Vercelli D, Polverino F, Billheimer D, Kraft M (2020) Type 2 inflammation modulates ACE2 and TMPRSS2 in airway epithelial cells. J Allergy Clin Immunol 146(1):80-88. https://doi.org/10.1016/j. jaci.2020.05.004

39. Jackson DJ, Busse WW, Bacharier LB, Kattan M, O'Connor GT, Wood RA, Visness CM, Durham SR, Larson D, Esnault S, Ober C, Gergen PJ, Becker P, Togias A, Gern JE, Altman MC (2020) Association of respiratory allergy, asthma, and expression of the SARS-CoV-2 receptor ACE2. J Allergy Clin Immunol 146(1):203-206. https://doi.org/10.1016/j.jaci.2020.04.009

40. Peters MC, Sajuthi S, Deford P, Christenson S, Rios CL, Montgomery MT, Woodruff PG, Mauger DT, Erzurum SC, Johansson MW, Denlinger LC, Jarjour NN, Castro M, Hastie AT, Moore W, Ortega VE, Bleecker ER, Wenzel SE, Israel E, Levy BD, Seibold MA, Fahy JV (2020) COVID-19-related genes in sputum cells in asthma. Relationship to demographic features and corticosteroids. Am J Respir Crit Care Med 202(1):83-90. https://doi.org/10.1164/ rccm.202003-08210C

41. Heurich A, Hofmann-Winkler H, Gierer S, Liepold T, Jahn O, Pöhlmann S (2014) TMPRSS2 and ADAM17 cleave ACE2 differentially and only proteolysis by TMPRSS 2 augments entry driven by the severe acute respiratory syndrome coronavirus spike protein. J Virol 88(2):1293-1307. https://doi.org/10.1128/JVI.02202 $-13$

42. Lambert DW, Yarski M, Warner FJ, Thornhill P, Parkin ET, Smith AI, Hooper NM, Turner AJ (2005) Tumor necrosis factor-alpha convertase (ADAM17) mediates regulated ectodomain shedding of the severe-acute respiratory syndrome-coronavirus (SARS$\mathrm{CoV}$ ) receptor, angiotensin-converting enzyme-2 (ACE2). J Biol Chem 280(34):30113-30119. https://doi.org/10.1074/jbc.M5051 11200

43. Haga S, Nagata N, Okamura T, Yamamoto N, Sata T, Yamamoto N, Sasazuki T, Ishizaka Y (2010) TACE antagonists blocking ACE2 shedding caused by the spike protein of SARS-CoV are candidate antiviral compounds. Antiviral Res 85(3):551-555. https://doi.org/10.1016/j.antiviral.2009.12.001

44. Haga S, Yamamoto N, Nakai-Murakami C, Osawa Y, Tokunaga K, Sata T, Yamamoto N, Sasazuki T, Ishizaka Y (2008) Modulation of TNF-alpha-converting enzyme by the spike protein of
SARS-CoV and ACE2 induces TNF-alpha production and facilitates viral entry. Proc Natl Acad Sci USA 105(22):7809-7814. https://doi.org/10.1073/pnas.0711241105

45. Hoffmann M, Kleine-Weber H, Schroeder S, Krüger N, Herrler T, Erichsen S, Schiergens TS, Herrler G, Wu NH, Nitsche A, Müller MA, Drosten C, Pöhlmann S (2020) SARS-CoV-2 cell entry depends on ACE2 and TMPRSS2 and is blocked by a clinically proven protease inhibitor. Cell 181(2):271-280. https://doi. org/10.1016/j.cell.2020.02.052

46. Shulla A, Heald-Sargent T, Subramanya G, Zhao J, Perlman S, Gallagher T (2011) A transmembrane serine protease is linked to the severe acute respiratory syndrome coronavirus receptor and activates virus entry. J Virol 85(2):873-882. https://doi. org/10.1128/JVI.02062-10

47. Jia HP, Look DC, Tan P, Shi L, Hickey M, Gakhar L, Chappell MC, Wohlford-Lenane C, McCray PB Jr (2009) Ectodomain shedding of angiotensin converting enzyme 2 in human airway epithelia. Am J Physiol Lung Cell Mol Physiol 297(1):L84-L96. https://doi.org/10.1152/ajplung.00071.2009

48. Ramchand J, Patel SK, Kearney LG, Matalanis G, Farouque O, Srivastava PM, Burrell LM (2020) Plasma ACE2 activity predicts mortality in aortic stenosis and is associated with severe myocardial fibrosis. JACC Cardiovasc Imaging 13(3):655-664. https:// doi.org/10.1016/j.jcmg.2019.09.005

49. Epelman S, Tang WH, Chen SY, Van Lente F, Francis GS, Sen S (2008) Detection of soluble angiotensin-converting enzyme 2 in heart failure: insights into the endogenous counter-regulatory pathway of the renin-angiotensin-aldosterone system. J Am Coll Cardiol 52(9):750-754. https://doi.org/10.1016/j.jacc.2008.02.088

50. Lambert DW, Clarke NE, Hooper NM, Turner AJ (2008) Calmodulin interacts with angiotensin-converting enzyme-2 (ACE2) and inhibits shedding of its ectodomain. FEBS Lett 582(2):385-390. https://doi.org/10.1016/j.febslet.2007.11.085

51. Li W, Zhang C, Sui J, Kuhn JH, Moore MJ, Luo S, Wong SK, Huang IC, Xu K, Vasilieva N, Murakami A, He Y, Marasco WA, Guan Y, Choe H, Farzan M (2005) Receptor and viral determinants of SARS-coronavirus adaptation to human ACE2. EMBO J 24(8):1634-1643. https://doi.org/10.1038/sj.emboj.7600640

52. Li Q, Cao Z, Rahman P (2020) Genetic variability of human angiotensin-converting enzyme 2 (hACE2) among various ethnic populations. Mol Genet Genomic Med 8(8):e1344. https:// doi.org/10.1002/mgg3.1344

53. Benetti E, Tita R, Spiga O, Ciolfi A, Birolo G, Bruselles A, Doddato G, Giliberti A, Marconi C, Musacchia F, Pippucci T, Torella A, Trezza A, Valentino F, Baldassarri M, Brusco A, Asselta R, Bruttini M, Furini S, Seri M, Nigro V, Matullo G, Tartaglia M, Mari F, GEN-COVID Multicenter Study, Renieri A, Pinto AM (2020) ACE2 gene variants may underlie interindividual variability and susceptibility to COVID-19 in the Italian population. Eur J Hum Genet 28(11):1602-1614

54. Guo X, Chen Z, Xia Y, Lin W, Li H (2020) Investigation of the genetic variation in ACE2 on the structural recognition by the novel coronavirus (SARS-CoV-2). J Transl Med 18(1):321. https ://doi.org/10.1186/s12967-020-02486-7

55. Rehman SU, Tabish M (2020) Alternative splicing of ACE2 possibly generates variants that may limit the entry of SARS-CoV-2: a potential therapeutic approach using SSOs. Clin Sci (Lond) 134(10):1143-1150. https://doi.org/10.1042/CS20200419

56. Irham LM, Chou WH, Calkins MJ, Adikusuma W, Hsieh SL, Chang WC (2020) Genetic variants that influence SARS-CoV-2 receptor TMPRSS2 expression among population cohorts from multiple continents. Biochem Biophys Res Commun 529(2):263269. https://doi.org/10.1016/j.bbrc.2020.05.179

57. Ciaglia E, Vecchione C, Puca AA (2020) COVID-19 infection and circulating ACE2 levels: protective role in women and children. Front Pediatr 8:206. https://doi.org/10.3389/fped.2020.00206 
58. Kornilov SA, Lucas I, Jade K, Dai CL, Lovejoy JC, Magis AT (2020) Plasma levels of soluble ACE2 are associated with sex, metabolic syndrome, and its biomarkers in a large cohort, pointing to a possible mechanism for increased severity in COVID-19. Crit Care 24(1):452. https://doi.org/10.1186/s13054-020-03141-9

59. Swärd P, Edsfeldt A, Reepalu A, Jehpsson L, Rosengren BE, Karlsson MK (2020) Age and sex differences in soluble ACE2 may give insights for COVID-19. Crit Care 24(1):221. https://doi. org/10.1186/s13054-020-02942-2

60. Lumpuy-Castillo J, Lorenzo-Almorós A, Pello-Lázaro AM, Sánchez-Ferrer C, Egido J, Tuñón J, Peiró C, Lorenzo Ó (2020) Cardiovascular damage in COVID-19: therapeutic approaches targeting the renin-angiotensin-aldosterone system. Int J Mol Sci 21(18):6471. https://doi.org/10.3390/ijms21186471

61. Glowacka I, Bertram S, Herzog P, Pfefferle S, Steffen I, Muench MO, Simmons G, Hofmann H, Kuri T, Weber F, Eichler J, Drosten C, Pöhlmann S (2010) Differential downregulation of ACE2 by the spike proteins of severe acute respiratory syndrome coronavirus and human coronavirus NL63. J Virol 84(2):1198-1205. https://doi.org/10.1128/JVI.01248-09

62. Imai Y, Kuba K, Rao S, Huan Y, Guo F, Guan B, Yang P, Sarao R, Wada T, Leong-Poi H, Crackower MA, Fukamizu A, Hui CC, Hein L, Uhlig S, Slutsky AS, Jiang C, Penninger JM (2005) Angiotensin-converting enzyme 2 protects from severe acute lung failure. Nature 436(7047):112-116. https://doi.org/10.1038/natur e03712

63. Papp M, Li X, Zhuang J, Wang R, Uhal BD (2002) Angiotensin receptor subtype AT(1) mediates alveolar epithelial cell apoptosis in response to ANG II. Am J Physiol Lung Cell Mol Physiol 282(4):L713-L718. https://doi.org/10.1152/ajplung.00103.2001

64. Welch WJ (2008) Angiotensin II-dependent superoxide: effects on hypertension and vascular dysfunction. Hypertension 52(1):5156. https://doi.org/10.1161/HYPERTENSIONAHA.107.090472

65. Dikalova A, Clempus R, Lassègue $\mathrm{B}$, Cheng G, McCoy J, Dikalov S, San Martin A, Lyle A, Weber DS, Weiss D, Taylor WR, Schmidt HH, Owens GK, Lambeth JD, Griendling KK (2005) Nox 1 overexpression potentiates angiotensin II-induced hypertension and vascular smooth muscle hypertrophy in transgenic mice. Circulation 112(17):2668-2676. https://doi.org/10.1161/CIRCU LATIONAHA.105.538934

66. Jones ES, Vinh A, McCarthy CA, Gaspari TA, Widdop RE (2008) AT2 receptors: functional relevance in cardiovascular disease. Pharmacol Ther 120(3):292-316. https://doi.org/10.1016/j.pharm thera.2008.08.009

67. Marchesi C, Paradis P, Schiffrin EL (2008) Role of the reninangiotensin system in vascular inflammation. Trends Pharmacol Sci 29(7):367-374. https://doi.org/10.1016/j.tips.2008.05.003

68. Hrenak J, Paulis L, Simko F (2016) Angiotensin A/Alamandine/ MrgD axis: another clue to understanding cardiovascular pathophysiology. Int J Mol Sci 17(7):1098. https://doi.org/10.3390/ ijms 17071098

69. Schmaier AH (2002) The plasma kallikrein-kinin system counterbalances the renin-angiotensin system. J Clin Invest 109(8):10071009. https://doi.org/10.1172/JCI15490

70. Kashuba E, Bailey J, Allsup D, Cawkwell L (2013) The kininkallikrein system: physiological roles, pathophysiology and its relationship to cancer biomarkers. Biomarkers 18(4):279-296. https://doi.org/10.3109/1354750X.2013.787544

71. Su JB (2014) Different cross-talk sites between the renin-angiotensin and the kallikrein-kinin systems. J Renin Angiotensin Aldosterone Syst 15(4):319-328. https://doi.org/10.1177/14703 20312474854

72. Rahman AM, Murrow JR, Ozkor MA, Kavtaradze N, Lin J, De Staercke C, Hooper WC, Manatunga A, Hayek S, Quyyumi AA (2014) Endothelium-derived hyperpolarizing factor mediates bradykinin-stimulated tissue plasminogen activator release in humans. J Vasc Res 51(3):200-208. https://doi. org $/ 10.1159 / 000362666$

73. Qadri F, Bader M (2018) Kinin B1 receptors as a therapeutic target for inflammation. Expert Opin Ther Targets 22(1):31-44. https://doi.org/10.1080/14728222.2018.1409724

74. Murugesan P, Jung B, Lee D, Khang G, Doods H, Wu D (2016) Kinin B1 receptor inhibition with BI113823 reduces inflammatory response, mitigates organ injury, and improves survival among rats with severe sepsis. J Infect Dis 213(4):532-540. https://doi.org/10.1093/infdis/jiv426

75. Sodhi CP, Wohlford-Lenane C, Yamaguchi Y, Prindle T, Fulton WB, Wang S, McCray PB Jr, Chappell M, Hackam DJ, Jia H (2018) Attenuation of pulmonary ACE2 activity impairs inactivation of des-Arg ${ }^{9}$ bradykinin/BKB1R axis and facilitates LPSinduced neutrophil infiltration. Am J Physiol Lung Cell Mol Physiol 314(1):L17-L31. https://doi.org/10.1152/ajplung.00498 .2016

76. van de Veerdonk FL, Netea MG, van Deuren M, van der Meer JW, de Mast Q, Brüggemann RJ, van der Hoeven H (2020) Kallikrein-kinin blockade in patients with COVID-19 to prevent acute respiratory distress syndrome. Elife 9:e57555. https://doi. org/10.7554/eLife.57555

77. Ingraham NE, Barakat AG, Reilkoff R, Bezdicek T, Schacker T, Chipman JG, Tignanelli CJ, Puskarich MA (2020) Understanding the renin-angiotensin-aldosterone-SARS-CoV axis: a comprehensive review. Eur Respir J 56(1):2000912. https://doi. org/10.1183/13993003.00912-2020

78. Warner FJ, Smith AI, Hooper NM, Turner AJ (2004) Angiotensin-converting enzyme-2: a molecular and cellular perspective. Cell Mol Life Sci 61(21):2704-2713. https://doi.org/10.1007/ s00018-004-4240-7

79. Gouda AS, Mégarbane B (2020) Snake venom-derived bradykinin-potentiating peptides: a promising therapy for COVID-19? Drug Dev Res. https://doi.org/10.1002/ddr.21732

80. Davidson AM, Wysocki J, Batlle D (2020) Interaction of SARSCoV-2 and other Coronavirus with ACE (Angiotensin-Converting Enzyme)-2 as their main receptor: therapeutic implications. Hypertension 76(5):1339-1349. https://doi.org/10.1161/ HYPERTENSIONAHA.120.15256

81. Haschke M, Schuster M, Poglitsch M, Loibner H, Salzberg M, Bruggisser M, Penninger J, Krähenbühl S (2013) Pharmacokinetics and pharmacodynamics of recombinant human angiotensin-converting enzyme 2 in healthy human subjects. Clin Pharmacokinet 52(9):783-792. https://doi.org/10.1007/s4026 2-013-0072-7

82. Khan A, Benthin C, Zeno B, Albertson TE, Boyd J, Christie JD, Hall R, Poirier G, Ronco JJ, Tidswell M, Hardes K, Powley WM, Wright TJ, Siederer SK, Fairman DA, Lipson DA, Bayliffe AI, Lazaar AL (2017) A pilot clinical trial of recombinant human angiotensin-converting enzyme 2 in acute respiratory distress syndrome. Crit Care 21(1):234. https://doi.org/10.1186/s1305 4-017-1823-x

83. Monteil V, Kwon H, Prado P, Hagelkrüys A, Wimmer RA, Stahl M, Leopoldi A, Garreta E, Hurtado Del Pozo C, Prosper F, Romero JP, Wirnsberger G, Zhang H, Slutsky AS, Conder R, Montserrat N, Mirazimi A, Penninger JM (2020) Inhibition of SARS-CoV-2 infections in engineered human tissues using clinical-grade soluble human ACE2. Cell 181(4):905-913. https://doi. org/10.1016/j.cell.2020.04.004

84. Inal JM (2020) Decoy ACE2-expressing extracellular vesicles that competitively bind SARS-CoV-2 as a possible COVID-19 therapy. Clin Sci (Lond) 34(12):1301-1304. https://doi.org/10.1042/ CS20200623

85. Kruse RL (2020) Therapeutic strategies in an outbreak scenario to treat the novel coronavirus originating in Wuhan, China. F1000Res 9:72. https://doi.org/10.12688/f1000research.22211.2 
86. Saeedi Saravi SS, Beer JH (2020) Apelin-potential therapy for COVID-19? J Mol Cell Cardiol 145:84-87. https://doi. org/10.1016/j.yjmcc.2020.06.007

87. Perrotta F, Corbi G, Mazzeo G, Boccia M, Aronne L, D’Agnano V, Komici K, Mazzarella G, Parrella R, Bianco A (2020) COVID19 and the elderly: insights into pathogenesis and clinical decision-making. Aging Clin Exp Res 32(8):1599-1608. https://doi. org/10.1007/s40520-020-01631-y

88. Perrotta F, Matera MG, Cazzola M, Bianco A (2020) Severe respiratory SARS-CoV2 infection: does ACE2 receptor matter? Respir Med 168:105996. https://doi.org/10.1016/j. rmed.2020.105996
Publisher's Note Springer Nature remains neutral with regard to jurisdictional claims in published maps and institutional affiliations. 